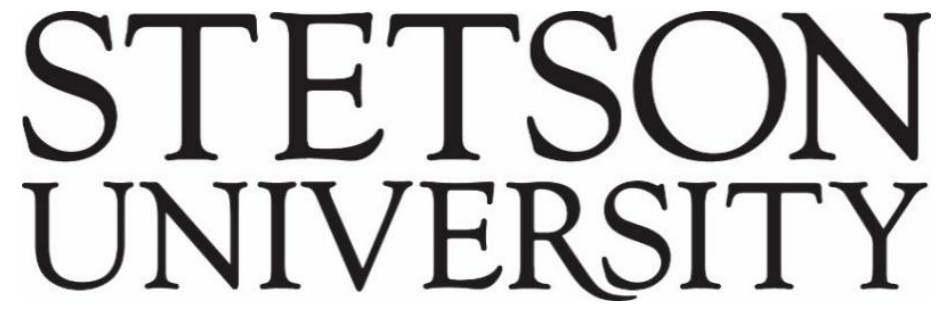

Voices of Reform: Educational Research to Inform and Reform

Volume 2・Issue $1 \bullet$ Article 4

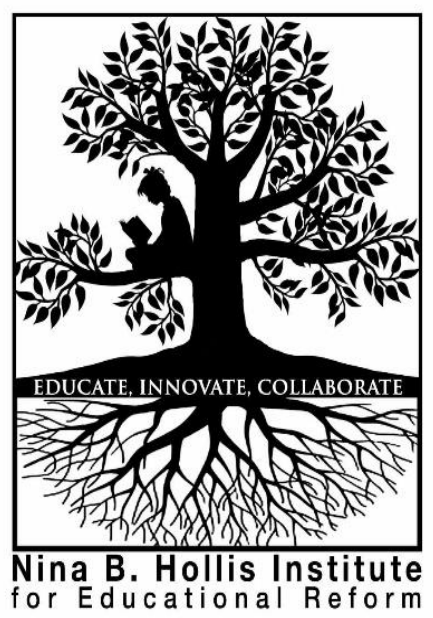

September 2019

\title{
Why is it so Hard to Send My Kid to a Good Preschool? The Shocking Truth about Early Education in America
}

Hani Morgan

University of Southern Mississippi

Follow this and additional works at: http://www.voicesofreform.com

Recommended Citation

Morgan, H. (2019). Why is it so hard to send my kid to a good preschool? The shocking truth about early education in America. Voices of Reform, 2(1), 59-72. Retrieved from https://www.voicesofreform.com/article/10610-why-isit-so-hard-to-send-my-kid-to-a-good-preschool-the-shocking-truth-about-early-education-in-america doi: $10.32623 / 2.00006$

http://dx.doi.org/10.32623/2.00006

Revisions

Submission date: January $9^{\text {th }}, 2019$

$1^{\text {st }}$ Revision: March $5^{\text {th }}, 2019$

Acceptance: March 12 ${ }^{\text {th }}, 2019$

Publication date: September 30 2019 


\title{
Why is it So Hard to Send My Kid to a Good Preschool? The Shocking Truth about Early Education in America
}

\author{
Hani Morgan ${ }^{1}$ \\ ${ }^{1}$ School of Education \\ University of Southern Mississippi, United States \\ hani.morgan@usm.edu
}

\begin{abstract}
In comparison with other industrialized nations, the United States is behind in early education. In addition, students from low-income families are less likely to enroll in preschool than their more privileged counterparts and more likely to attend low-quality programs. This situation harms American students and society. This essay documents the results of various studies showing that high-quality preschool benefits children. It also offers reasons for improving preschool access and quality in the United States and includes examples of strategies for achieving this goal.
\end{abstract}

\section{Keywords}

early childhood education, poverty, program administration

\section{Introduction}

The United States is behind most industrialized countries in early education. A recent report from the Organization for Economic Cooperation and Development (OECD) indicated that only about $70 \%$ of 4-year-olds and $40 \%$ of 3-year-olds were enrolled in U.S. preschool programs. These are low percentages because more than $90 \%$ of 4-year-olds were recently enrolled in preschool in many countries, and the average enrollment for 3-year-olds was about $70 \%$ (Camera, 2017). In 2015, OECD data showed that only 54\% of 3- and 4-year-olds in the United States were enrolled in preschool but that OECD countries had an $80 \%$ average enrollment rate. These statistics indicated that the United States had an enrollment rate well below the OECD average and that over 25 countries had higher enrollment rates at this age level (National Center for Education Statistics, 2018).

The high cost of early education and the lack of publicly funded preschool programs in the United States contribute to these low rates. In comparison with other wealthy nations, the United States 
spends little on early education (Mongeau, 2018). The National Institute for Early Education Research (NIEER) reported that only $32 \%$ of 4 -year-olds and $5 \%$ of 3-year-olds were enrolled in state-funded preschool programs in recent years (Barnett et al., 2017).

This analytic essay offers reasons for improving preschool education in the United States and focuses on the benefits of providing access to high-quality early education programs for the poor. It also mentions why some policymakers might resist improving preschool programs and includes a few strategies for providing more access and better quality.

\section{Lack of High-Quality Programs for Low-Income Families}

The most serious problem involving preschool education in America is the lack of access to highquality programs for low-income families. Many studies mentioned in this paper provide overwhelming evidence that high-quality preschool benefits low-income children greatly. Unfortunately, children from underprivileged families are less likely to be enrolled in preschool than their more privileged counterparts. And when they are enrolled, they are more likely to attend low-quality programs (Morgan, 2019; U.S. Department of Education, 2015).

One reason for this lack of access is that Head Start— the largest publicly funded child federal program for children from low-income families in the United States - is underfunded. Although in 2014-2015 the federal government spent over $\$ 8$ billion on Head Start programs for children and pregnant women, it was insufficient to enroll all eligible children. During these years, Head Start programs only served about $36 \%$ of children in poverty (Barnett \& Friedman-Krauss, 2016).

Another problem with Head Start is that it provides low quality on average (Cascio \& Schanzenbach, 2014). And it varies greatly from state to state not only in quality but in access: "Although in some states Head Start meets evidence-based quality standards and serves a high percentage of low-income children statewide, in other states Head Start reaches fewer of those in need, often with low-quality instruction, and insufficient hours" (Barnett \& Friedman-Krauss, 2016 , p. 4). One reason for this low quality involves the low level of teacher qualifications and pay. Head Start teachers earn about half of what public school teachers make. And only about half of them hold bachelor's degrees (Barnett \& Frede, 2010).

Further, many preschool programs do not adhere to national standards. For example, few states comply with all of the minimum standards the National Institute for Early Education Research (NIEER) uses to evaluate early education programs. These standards require a bachelor's degree for lead teachers and a Child Development Associate (CDA) credential for assistant teachers. In 2015, only seven states fully complied with NIEER's 10 minimum standards (Washington, 2017).

\section{Characteristics of High-Quality Preschools}

So what constitutes high-quality early education? According to the Learning Policy Institute (2016), high-quality early education includes the following elements:

- A developmentally appropriate curriculum and standards that address the whole child

- An engaging classroom environment that promotes learning 
- Well-prepared teachers who receive ongoing support, including mentoring

- Low student to teacher ratios

- A state quality rating system that is well implemented

- Support for students with special needs and English learners

- Assessments that influence instructional planning and that focus on children's social, emotional, physical, and academic progress

- Purposeful family engagement

One way to tell if a preschool offers high-quality early education is by investigating whether or not it has achieved accreditation by the National Association for the Education of Young Children (NAEYC). This association accredits preschools using a rigorous improvement system that includes unannounced quality-assurance visits. Achieving NAEYC accreditation is a sign that a preschool provides high-quality early education. Unfortunately, less than $10 \%$ of all child care centers, kindergartens, and preschools achieve NAEYC accreditation (National Association for the Education of Young Children, 2018). NAEYC accredits preschools based on how they fulfill 10 standards:

- Standard 1 emphasizes relationships and focuses on developing favorable relationships among all children and adults.

- Standard 2 indicates that the curriculum needs to promote learning and to develop the social, physical, emotional, language, and cognitive areas.

- Standard 3 mentions that teaching needs to be based on developmentally, culturally, and linguistically appropriate practices.

- Standard 4 focuses on assessment and indicates that it needs to involve formal and informal assessment approaches that are culturally sensitive.

- Standard 5 emphasizes the nutrition and health of children, protecting them from injury and illness.

- Standard 6 focuses on the competencies of the staff and indicates that a program needs to employ personnel with the qualifications and commitment needed to promote children's learning.

- Standard 7 mentions that a program needs to have collaborative relationships with children's families to promote their development.

- Standard 8 indicates that relationships with the children's communities need to be developed to help the program thrive and connect families with the resources that promote children's healthy development. 
- Standard 9 states that the program needs to provide a healthful and safe environment that includes well-maintained indoor and outdoor physical environments.

- Standard 10 focuses on leadership and management and mentions that the program needs to implement policies that support stable and strong personnel to allow all children, families, and staff to have high-quality experiences.

\section{The Advantages of High-Quality Early Education}

The lack of preschool programs that adhere to the recommendations of professional organizations such as NAEYC is harmful to children and society. High-quality early learning experiences are critical because the human brain develops through a process that starts before birth and continues into adulthood. The experiences children have early in life affect the brain greatly and contribute to either a strong or weak foundation for future learning (Center on the Developing Child, 2007). The preschool years are crucial for a child's future success because the brain grows at a rapid rate during this period. Indeed, before the age of six, the human brain quadruples in weight, reaching about $90 \%$ of its adult volume (Brown \& Jernigan, 2012).

If children fail to receive adequate early learning experiences, they will endure more academic problems and require remediation later in life (Center on the Developing Child, 2007). In addition, the failure to provide early education is costly. Professor James Heckman, a leading economist with expertise in child development, estimated that increasing the high school graduation rates of the most disadvantaged children by about $20 \%$ would cost considerably more if the assistance is offered during their teens rather than before age six (Porter, 2013).

Professor Heckman and his colleagues recently published a study indicating that high-quality birth-to-five programs for disadvantaged children lead to many positive outcomes. These outcomes include improvement in education, social behaviors, health, and employment. Such improvements will strengthen the United States' future workforce and will also reduce taxpayer costs (Heckman, 2017).

\section{Research on the Advantages of Preschool}

Professor Heckman's recent study is not the only one that highlights the benefits of enrolling in high-quality preschool. Other recent research indicates that early education improves the lives of children and society. Elizabeth Cascio (2017), for example, concluded from her study that universal state-funded preschool leads to positive outcomes in reading for low-income 4-year-olds. She also found that state preschool programs targeted toward low-income children did not generate these results, possibly because universal programs attract better teachers who set high expectations as a result of being under more parental pressure.

Other authors, such as W. Steven Barnett (2010), mentioned that both targeted and universal preschool programs have been shown to enhance the development and learning of low-income children. According to some studies, children who enroll in Head Start experience positive outcomes despite attending programs that can vary greatly in quality from state to state. For example, Shager et al. (2017) concluded from their meta-analysis that Head Start is effective in 
enhancing children's short-term cognitive and achievement outcomes. Their meta-analysis analyzed the findings of 28 Head Start programs.

In addition, the Head Start Impact Study showed that this program led to positive short-term effects. This study involved a large sample of randomly selected 3- and 4-year-olds who either attended Head Start or did not (Barnett, 2008). It involved over 4,000 children and revealed that those who were enrolled experienced improvement in academic skills and fewer behavioral problems. For 3-year-olds, for example, children experienced positive outcomes not only in literacy and math but also in health:

For the 3-year-old group, benefits were found in all four domains examined ... including impacts on vocabulary (PPVT), letter-word identification, pre-academic skills, letter naming, elision (phonological processing), parent-reported emergent literacy, McCarthy Draw-a-Design (perceptual motor skills and pre-writing), applied problems (math), hyperactive behavior, withdrawn behavior, dental care, health status, parent spanking, parent reading to child, and family cultural enrichment activities. (U. S. Department of Health and Human Services, Administration for Children and Families, 2010, p. xvi)

Improvements in health and in the ways parents relate to their children occurred because Head Start programs usually involve parents and provide comprehensive, dental, medical, nutrition, and social services (Barnett \& Friedman-Krauss, 2016).

Research on early education indicates that quality can make a difference. For instance, the findings of a meta-analysis that evaluated 32 studies indicated that teachers with less education had fewer positive effects on early education outcomes than their counterparts with a bachelor's degree (Kelly \& Camilli, 2007). This meta-analysis supported one of Barnett's (2004) policy recommendations urging for a requirement for preschool teachers to have a four-year college degree.

Another study suggesting that quality is important involved Oklahoma's universal pre-k program. This program was established in 1998 for 4-year-old children when school districts started to receive aid for each 4-year-old child they would enroll. Unlike other universal preschool programs, Oklahoma's requires all teachers to have a bachelor's degree and an early childhood certificate. In addition, Oklahoma offers pre-k teachers the same salary that other elementary and secondary school teachers receive. These factors contribute to the program's high-quality standards (Gormley, Gayer, Phillips, \& Dawson, 2005).

The study on Oklahoma's universal pre-k program included over 1,500 children who enrolled in the program. Gormley, Gayer, Phillips, and Dawson (2005) concluded that this program supported the idea that a universal pre-k program can improve prereading, prewriting, and pre-numeracy skills for a diverse group of children. The researchers mentioned that their results provide solid evidence that such programs can improve the test scores of children from differing socioeconomic backgrounds and from diverse ethnic and racial groups. When addressing the question of whether Oklahoma's program can be replicated in other states, they referred to the importance of Oklahoma's high teacher education requirements. And they noted that other researchers found 
these prerequisites to be a strong predictor of high-quality environments for young children (Gormley, Gayer, Phillips, \& Dawson, 2005).

Nelson, Westhues, and MacLeod's (2003) meta-analysis on 34 preschool prevention programs revealed that more intense interventions produced greater cognitive and parent-family outcomes. In other words, ongoing educational intervention that lasts after preschool was found to be more powerful in yielding positive outcomes. These researchers concluded that preschool education benefits children and that programs with a center-based or direct-teaching approach are superior to those without these components. In addition, they mentioned that early education produced positive short- and long-term outcomes and that it benefitted African American children the most. In their discussion, they mentioned that failing to provide preschool prevention programs for lowincome African American children is an extremely bad policy.

Another meta-analysis consisting of 123 early childhood intervention programs supported the use of teacher-directed instruction instead of student-directed learning with a teacher who acts as a facilitator. The researchers mentioned that individualized instruction contributed to a positive impact on cognitive outcomes. When individual or small-group instruction is implemented, it creates more chances for teachers to use content that matches children's developmental levels, enhancing children's learning of academic concepts (Camilli, Vargas, Ryan, \& Barnett, 2010).

\section{Research on the Oldest Preschool Intervention Programs}

Advocates of preschool education often refer to studies on two of the oldest preschool programs in America to emphasize the powerful effects of early education. One of these programs - the Perry Preschool Program — started during the early 1960s. This program is the oldest and most cited early childhood intervention (Heckman, Moon, Pinto, Savelyev, \& Yavitz, 2010). The program involved 123 low-income African-American children, with 58 in the program group. Unlike those in the program group, the remaining children did not attend preschool (Schweinhart et al., 2005). The program group went to the Perry Elementary School in Ypsilanti, Michigan. Starting at age 3 , these children attended the program for $2 \frac{1}{2}$ hours a day on weekdays and experienced weekly home visits by teachers. The teachers promoted active learning by encouraging children to plan, participate in, and reflect on their activities (Heckman, Moon, Pinto, Savelyev, \& Yavitz, 2010).

The home visits occurred in the afternoons and lasted 1 to $1 \frac{1}{2}$ hours. The teachers brought materials including crayons, books, pens, and paper, and worked with both children and parents. Parents were informed about what went on at the school during the week, and the teachers expressed concerns about the children when they wanted the parents' perspectives (Derman-Sparks, 2016).

The participants were interviewed in later years when they were 15, 19, 27, and 40 years of age. And researchers collected data consisting of school, welfare, and police records. The data revealed that the program benefitted the participants in various ways. For example, the females in the treatment group experienced higher GPAs, received special education less often, and progressed through grades at a faster rate. Although the males experienced few, if any, improvements related to education attainment (Heckman, Moon, Pinto, Savelyev, \& Yavitz, 2009), they benefited in other ways. When they were 40 , for instance, more males in the program group were employed 
than those in the no-program group (70\% vs. 50\%). In addition, the program was found to reduce overall arrests, including arrests for violent and drug crimes (Schweinhart et al., 2005).

Another early preschool program often mentioned for emphasizing the need for better preschool programs is the Carolina Abecedarian Project. This project started in 1972 in Chapel Hill, North Carolina. It involved a treatment and a control group of disadvantaged children, with 57 assigned to the treatment group and 54 to the control group (Campbell et al., 2014). This program was more intensive as children stayed $6 \frac{1}{2}$ to 10 hours a day. In addition, some children enrolled at a younger age than those in the Perry study. And the Abecedarian Project did not include home visits. Unlike the Perry intervention, the Abecedarian Project had a nutritional and health care component, allowing children to eat meals and snacks and to receive free pediatric care (Conti, Heckman, \& Pinto, 2015).

Although these two programs differed in some ways, they shared some qualities. Like the Perry Preschool Program, the Abecedarian Project was a small-scale, center-based program designed to enhance the lives of disadvantaged children. The two programs also focused on cognitive and language development, the use of field trips, and a curriculum allowing individual adaptation (Conti, Heckman, \& Pinto, 2015).

The Abecedarian Project enhanced the health of those in the treatment group in various ways. For example, participants experienced fewer risk factors for metabolic and cardiovascular diseases in their thirties and a healthier body mass in their childhood years that continued into adulthood (Campbell et al., 2014). The program was also associated with impressive educational gains up to age 30 (Campbell et al., 2012). For instance, 23\% of those in the treatment group received a bachelor's degree by age 30 , but only $6 \%$ of the control group achieved this goal. This program provided evidence that very early childcare is critical for enhancing the development of children from low-income families in need of out-of-home care (Campbell et al., 2012).

\section{Opposing Views on the Impact of Preschool Education}

Although research on high-quality preschool programs clearly shows that it can make a positive impact on children's lives, not everyone is convinced that increased access to preschool will benefit society. Those who doubt the benefits offer a variety of reasons, often criticizing the research on early education. Skeptics of the Perry Preschool Program, for instance, refer to the small sample size of 123 treatments and controls. They also point to the lack of statistical significance for the treatment effects and the long-term effects on IQ of the program (Heckman, Moon, Pinto, Savelyev, \& Yavitz, 2009).

However, referring to the small sample size of this program, or to the one of the Abecedarian Project, to argue against the need for more access to high-quality preschool is a poor approach. The many aforementioned studies with large sample sizes clearly show the benefits of preschool education. Further, in response to some of the weaknesses of older research, Heckman, Moon, Pinto, Savelyev, and Yavitz (2009) analyzed the results of the Perry Preschool Project and still found it to be beneficial. They focused on the program's rate of return because those who favor enhancing early education often say it promotes economic efficiency. They concluded that the program's rate of return was between $7 \%$ and $10 \%$. In other words, every dollar invested in high- 
quality early childhood education for disadvantaged children yielded a $7 \%$ to $10 \%$ annual return (Heckman, 2011).

Some critics point to the Tennessee Preschool Study. Launched in 2009 and organized by Vanderbilt's Peabody Research Institute and the Tennessee Department of Education, this study explored the effects of preschool through elementary school. It involved a sample of 1076 children, with 773 who attended the program and 303 who did not. The findings indicated that the children enrolled in the program made initial strong gains. Their teachers even perceived them as betterprepared students. But by the end of kindergarten, the control children caught up. And by the second and third grades, the control children outperformed the pre-k children academically (Farran \& Lipsey, 2015).

However, the likely cause for the disappointing results is poor quality. An article in the New York Times mentioned that the program lacked a coherent vision (Kirp, 2017). What probably contributed to the results was an overemphasis on direct instruction and a repetitive approach to teaching that led children to lose their enthusiasm for learning (Christakis, 2016). Professor William T. Gormley of Georgetown University suggested that the results of this study may have been due to the kindergarten and elementary teachers' lack of training on teaching students who had completed pre-k programs. He also mentioned the agreement among scholars that preschool enhances school readiness (Hoban, 2016). The researchers of the program themselves confirmed Professor Gormley's hypothesis about the chance that some of the teachers failed to provide appropriate instruction:

One possible explanation for why the gains children made in VPK [the Tennessee Voluntary Pre-K Program] did not continue to advantage them afterwards is failure of kindergarten and later teachers to build on the skills those children bring from their pre-k experience. (Lipsey, Farran, \& Durkin, 2018, p. 174)

In addition, they mentioned the need to consider a body of research rather than just their study before forming conclusions (Lipsey, Farran, \& Durkin, 2018).

Critics also refer to the Head Start Impact Study to argue against increasing access to preschool. Although children made academic gains before kindergarten according to this study, the gains were gone by the time they reached third grade (Barnett \& Friedman-Krauss, 2016). But as previously discussed, Head Start has been found to offer poor quality in many states and has been criticized for providing low quality on average. Therefore, pointing to this program to argue against the value of high-quality preschool makes no sense. In addition, efforts have been made to improve Head Start ever since it was launched in 1965. For instance, to improve its quality, the American Recovery and Reinvestment Act increased Head Start funding by \$2 billion in 2009 (Barnett \& Friedman-Krauss, 2016). Therefore, Head Start is likely to provide higher quality today than it did in previous years. Researchers also need to consider that like the children in the Tennessee Preschool Program, those in the Head Start Impact Study might have lost the gains they made in preschool because their future teachers failed to instruct them adequately. Such an outcome is a strong possibility since low-income students in the United States usually attend inferior elementary schools (Morgan, 2018). 


\section{Strategies for Improving Preschool Education}

The evidence provided thus far shows that those who raise doubts about the benefits of high-quality preschool usually use poor logic. Therefore, the issue that policymakers need to deal with does not involve how valuable high-quality preschool is but how to increase its access for all children.

This is a difficult concern to resolve because even advocates of early education disagree on this topic (Wong, 2014). The controversy frequently involves whether to implement universal preschool or to improve the quality and access of targeted programs. It can be difficult to determine the best approach because the learning gains low-income students make from universal preschool programs are greater than those higher-income children make (Cascio \& Schanzenbach, 2014). Low-income students make more gains from universal preschool because they learn more when they interact with peers with high levels of language and math skills (Reid, Kagan, Hilton, \& Potter 2015). However, universal preschool might not be cost effective in certain cases because the funds needed to implement it might exceed the benefits higher-income children experience. The problem is that universal preschool offers income support to wealthier families who can afford early education (Cascio, 2015). Although universal preschool appears to promote equity, targeted programs may lead to the same benefits for less cost:

High-quality universal early education can promote more equitable outcomes, both in school and in adulthood. However, the benefits for the most advantaged children may be lower than the costs of their participation. While the overall program benefits may still exceed program costs, policymakers should consider the possibility that income-targeted policies could yield the same benefits for less cost. (Cascio, 2015, p. 1)

\section{Conclusion}

High-quality preschool education benefits children in many ways. Many studies have shown that investing in early education would lead to significant societal returns by leading to a bettereducated future workforce that would increase American productivity. Such an investment would reduce socioeconomic inequalities as well (Bivens, García, Gould, Weiss, \& Wilson, 2016). Although critics point to studies showing that certain programs produced poor results, prominent researchers say that these studies likely investigated inferior programs and that high-quality programs yielded favorable outcomes. Further, some children may fail to show progress after preschool not because of the ineffectiveness of pre-k programs but because of kindergarten and elementary teachers' lack of training on teaching children who have completed preschool (Lipsey, Farran, \& Durkin, 2018).

Implementing universal preschool is the ideal strategy because this approach benefits low-income students the most. In addition to increasing access for low-income children, state-funded universal preschool would allow more middle class families to attend preschool. The high cost of private preschool programs makes them unaffordable for many middle class families. For example, the average cost of preschool for a 4-year-old in Massachusetts is higher than the average in-state college tuition (Wolff-Mann, 2016). 
Unfortunately, some states may lack the funds to implement high-quality universal preschool. Further, targeted programs may lead to similar gains for less cost because children from wealthy families usually benefit less from universal preschool than their low-income counterparts and do not need funded programs to attend. Improving preschool education in the United States is a difficult topic also because states vary considerably with regard to the way it is implemented. As a result, what may work for one state may backfire in another.

To deal with these complications, Cascio \& Schanzenbach (2014) recommended three strategies:

1. Implementing smaller, high-quality targeted programs for areas with no public preschool

2. Improving the quality in areas with low-quality programs before increasing access

3. Improving access in areas with high-quality programs that reach a small number of students

In implementing these strategies, a wise approach is to expand state preschool programs and to improve Head Start rather than permit states to take it over. Allowing states to take Head Start over would likely lead to problems for several reasons. First, as previously discussed, Head Start has a history of improving; therefore, it will likely continue to do so. Second, although some states have a strong commitment to early education, others do not. These states would likely not make much of an effort to enhance preschool programs even if provided with federal money as a result of taking over Head Start (Gordon \& Mead, 2014).

In improving Head Start, policymakers should start by discarding its annoying rules. Gordon and Mead (2014) discussed that these rules distract Head Start managers and prevent them from doing what it takes to ensure children are prepared for school. For example, the rules require programs to do at least two home visits for all students. A better approach is to vary these visits based on need, offering families with more problems three visits and others just one. Instead of following annoying performance standards, Head Start programs should adhere to a basic standard for quality, allowing each program to develop the models appropriate for their communities (Gordon \& Mead, 2014).

Another approach for improving early education is to encourage more university involvement designed to find solutions to the problems that affect today's children. Duke University, for example, has been involved in projects that deal with enhancing the lives of children and families. The Center for Child and Family Policy at Duke does work on the effect of economic distress on child development. One of their current programs focuses on providing services that promote the well-being of children through age three (Center for Child and Family Policy, n.d.).

One of the reasons high-quality early education is more important today than ever before relates to the increase in poverty in the 21 st century. The difference in wealth between the poor and the rich has increased greatly in the past few decades in the United States. Today, there is more income inequality in the United States than in most other wealthy countries (Morgan, 2016). Since children from low-income families benefit the most from early education, improving the educational opportunities for these children during their early years can alleviate a problem that has worsened in recent years. 
More researchers and authors need to become aware of the harmful effects of failing to provide high-quality early education. Scholars need to increase research on this topic and to make it widely available. Such an effort can lead policymakers to enact appropriate legislation. A stronger commitment to improving preschool education using these guidelines can create more opportunities for children to succeed later in life. Such a strategy will enhance their lives and the society they inhabit.

\section{References}

Barnett, W. S. (2004). Better teachers, better preschools: Student achievement linked to teacher qualifications. New Brunswick, NJ: National Institute for Early Education Research.

Barnett, W. S. (2008). Preschool education and its lasting effects: Research and policy implications. Boulder and Tempe: Education and the Public Interest Center \& Education Policy Research Unit.

Barnett, W. S. (2010). Universal and targeted approaches to preschool education in the United States. International Journal of Child Care and Education Policy, 4(1), 1-12.

Barnett, W. S., \& Frede, E. (2010). The promise of preschool: Why we need early education for all. American Educator, 34(1), 21-29.

Barnett, W. S., \& Friedman-Krauss, A. H. (2016). State(s) of Head Start. New Brunswick, NJ: National Institute for Early Education Research.

Barnett, W. S., Friedman-Krauss, A. H., Weisenfeld, G. G., Horowitz, M., Kasmin, R., \& Squires, J. H. (2017). The state of preschool 2016: State preschool yearbook. New Brunswick, NJ: National Institute for Early Education Research.

Bivens, J., García, E., Gould, E., Weiss, E., \& Wilson, V. (2016, April 6). It's time for an ambitious national investment in America's children. Economic Policy Institute. Retrieved from https://www.epi.org/publication/its-time-for-an-ambitious-national-investment-in-americas-children/

Brown, T. T., \& Jernigan, T. L. (2012). Brain development during the preschool years. Neuropsychology Review, 22(4), 313-333.

Camera, L. (2017, June 21). U.S. trails in early childhood education enrollment. U.S. News \& World Report. Retrieved from https://www.usnews.com/news/best-countries/articles/2017-06-21/us-falls-behind-otherdeveloped-countries-in-early-childhood-education-enrollment

Camilli, G., Vargas, S., Ryan, S., \& Barnett, W. S. (2010). Meta-analysis of the effects of early education interventions on cognitive and social development. Teachers College Record, 112(3), 579-620.

Campbell, F., Conti, G., Heckman, J. J., Moon, S. H., Pinto, R., Pungello, E., \& Pan, Y. (2014, March 28). Early childhood investments substantially boost adult health. Science, 343(6178), 1478-1485.

Campbell, F. A., Pungello, E. P., Burchinal, M., Kainz, K., Pan, Y., Wasik, B. H., Sparling, J. J., Barbarin, O. A., \& Ramey, C. T. (2012). Adult outcomes as a function of an early childhood educational program: An Abecedarian Project follow-up. Developmental Psychology, 48(4), 1033-1043.

Cascio, E. U. (2015). The promises and pitfalls of universal early education. IZA World of Labor. Retrieved from https://wol.iza.org/uploads/articles/116/pdfs/promises-and-pitfalls-of-universal-early-education.pdf

Cascio, E. U. (2017). Does universal preschool hit the target? Program access and preschool impact. Cambridge, MA: National Bureau of Economic Research.

Cascio, E. U., \& Schanzenbach, D. W. (2014). Expanding preschool access for disadvantaged children. In M. S. Kearney \& B. H. Harris (Eds.), Policies to address poverty in America (pp. 1-13). Washington, DC: The Brookings Institution.

Center for Child and Family Policy. (n.d.). Continuous, community-wide support for children and families to promote child well-being and kindergarten readiness. Retrieved from https://childandfamilypolicy.duke.edu/project/continuous-community-wide-support-children-familiespromote-child-well-kindergarten-readiness/

Center on the Developing Child. (2007). The science of early childhood development. Retrieved from https://developingchild.harvard.edu/resources/inbrief-science-of-ecd/

Conti, G., Heckman, J. J., \& Pinto, R. (2015). The effects of two influential early childhood interventions on health and healthy behavior. Working Paper 21454. Cambridge, MA: National Bureau of Economic Research. 
Christakis, E. (2016). The new preschool is crushing kids. The Atlantic. Retrieved from https://www.theatlantic.com/magazine/archive/2016/01/the-new-preschool-is-crushing-kids/419139/

Derman-Sparks, L. (2016). What I learned from the Ypsilanti Perry Preschool Project: A teacher's reflections. Journal of Pedagogy, 7(1), 93-106.

Farran, D. C., \& Lipsey, M. W. (2015, October 8). The Tennessee pre-k study. The Brookings Institution. Retrieved from https://www.brookings.edu/blog/up-front/2015/10/08/the-tennessee-pre-k-study/

Gormley, W. T., Gayer, T., Phillips, D., Dawson, B. (2005). The effects of universal pre-k on cognitive development. Developmental Psychology, 41(6), 872-884.

Heckman, J. J. (2011). The economics of inequality: The value of early childhood education. American Educator, $35(1), 31-35$.

Heckman, J. J., Moon, S. H., Pinto, R., Savelyev, P., \& Yavitz, A. (2009). The rate of return to the High/Scope Perry Preschool Program. Working Paper 15471. Cambridge, MA: National Bureau of Economic Research.

Heckman, J. J., Moon, S. H., Pinto, R., Savelyev, P., \& Yavitz, A. (2010). A new cost-benefit and rate of return analysis for the Perry Preschool Program: A summary. Working Paper 16180. Cambridge, MA: National Bureau of Economic Research.

Heckman, J. (2017, March 6). Economist James J. Heckman: Early education packs a high return on investment. The Committee for Economic Development of The Conference Board. Retrieved from https://www.ced.org/blog/entry/ comprehensive-birth-to-age-five-early-childhood-education-has-thehighest-r

Hoban, B. (2016, October 28). Does universal pre-school do more harm than good? The Brookings Institution. Retrieved from https://www.brookings.edu/blog/brookings-now/2016/10/28/watch-does-universal-preschool-do-more-harm-than-good/

Kelly, P., \& Camilli, G. (2007). The impact of teacher education on outcomes in center-based early childhood education programs: A meta-analysis. Retrieved from http://nieer.org/wpcontent/uploads/2016/08/TeacherEd.pdf

Kirp, D. L. (2015, October 3). Does pre-k make any difference? The New York Times. Retrieved from https://www.nytimes.com/2015/10/04/opinion/sunday/does-pre-k-make-any-difference.html

Learning Policy Institute. (2016). The building blocks of high-quality early childhood education programs. Retrieved from https://learningpolicyinstitute.org/product/ building-blocks-high-quality-early-childhoodeducation-programs

Lipsey, M. W., Farran, D. C., \& Durkin, K. (2018). Effects of the Tennessee Prekindergarten Program on children's achievement and behavior through third grade. Early Childhood Research Quarterly, 45, 155-176.

Mongeau, L. (2018, October 9). Time to change how we think about early education, international study finds. The Hechinger Report. Retrieved from https://hechingerreport.org/time-to-change-how-we-think-about-earlyeducation-international-study-finds/

Morgan, H. (2016). Relying on high-stakes standardized tests to evaluate schools and teachers: A bad idea. The Clearing House, 89(2), 67-72.

Morgan, H. (2018). The world's highest-scoring students: How their nations led them to excellence. New York: Peter Lang Publishing.

Morgan, H. (2019). Does high-quality preschool benefit children? What the research shows. Education Sciences, 9(1), 1-9.

National Association for the Education of Young Children. (2018). Kiddie Academy Gaithersburg presented with national NAEYC accreditation following surprise visit. Retrieved from https://www.naeyc.org/aboutus/news/press-releases/kiddie-academy-accreditation

National Center for Education Statistics (2018). The condition of education 2018. Retrieved from https://nces.ed.gov/pubs2018/2018144.pdf

Nelson, G., Westhues, A., \& MacLeod, J. (2003). A meta-analysis of longitudinal research on preschool prevention programs for children. Prevention and Treatment, 6, 1-35.

Porter, E. (2013, April 2). Investments in education may be misdirected. The New York Times. Retrieved from https://www.nytimes.com/2013/04/03/business/studies-highlight-benefits-of-early-education.html

Reid, J. L., Kagan, S. L., Hilton, M., \& Potter, H. (2015). A better start: Why classroom diversity matters in early education. New York, NY and Washington, DC: The Century Foundation and Poverty and Race Research Action Council.

Schweinhart, L. J., Montie, J., Xiang, Z., Barnett, W. S., Belfield, C. R., \& Nores, M., (2005). Lifetime effects: The High/Scope Perry Preschool Study through age 40. Ypsilanti, MI: High/Scope Press. 
Shager, H. M., Schindler, H. S., Magnuson, K. A., Duncan, G. J., Yoshikawa, H., \& Hart, C. M. (2013). Can research design explain variation in Head Start research results? A meta-analysis of cognitive and achievement outcomes. Educational Evaluation and Policy Analysis, 35, 76-95.

U. S. Department of Education. (2015). A matter of equity: Preschool in America. Retrieved from https://www2.ed.gov/documents/early-learning/matter-equity-preschool-america.pdf

U. S. Department of Health and Human Services, Administration for Children and Families. (2010). Head Start Impact Study: Final report. Retrieved from https://www.acf.hhs.gov/sites/default/files/opre/hs_impact_study_final.pdf

Washington, V. (2017). Universal pre-k: What we know, what we need. Virginia Journal of Education, 110(4), 1719.

Wolff-Mann, E. (2016, April 11). Is your state one of the 23 where pre-k costs more than college? Money. Retrieved from http://time.com/money/4289032/pre-k-costs-more-than-college-in-23-states/

Wong, A. (2014, November). The case against universal preschool. The Atlantic. Retrieved from https://www.theatlantic.com/education/archive/2014/11/the-case-against-universal-preschool/382853/ 